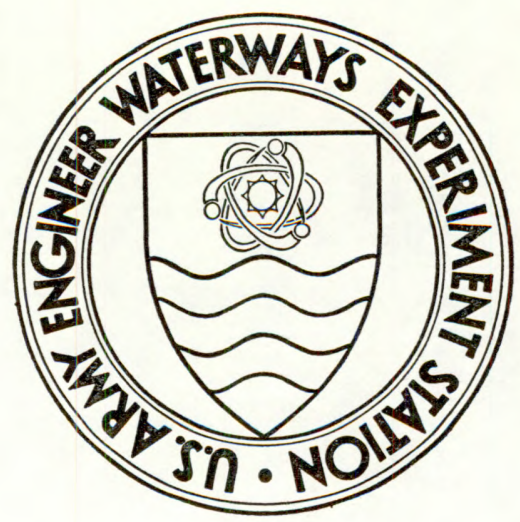

TECHNICAL REPORT N-73-6

\title{
BEHAVIOR OF LINED OPENINGS IN JOINTED AND UNJOINTED MODEL ROCK MASSES \\ by
}

J. G. Wallace

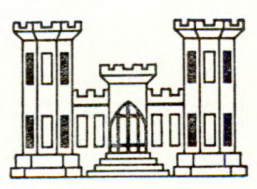

September 1973

Sponsored by Office, Chief of Engineers, U. S. Army

Project No. A880

Conducted by U. S. Army Engineer Waterways Experiment Station

Weapons Effects Laboratory

Vicksburg, Mississippi 